\title{
Budaya Hukum Ilmuwan tentang Hak Cipta: Suatu Penelitian Hukum Empiris
}

\author{
M. Syamsudin
}

\section{Abstract}

This writing is aimed to discuss either theoretically or empirically about the cultural law of scientist for copyright. The cultural law has a very large meaning, covers the values, ideas, knowledge, belief, attitude and societal behaviour to the law both positive and negative. In this writing, the law values and societal behaviour of the law becomes an indicator in knowing the law culture. Statistics is applied to assist analyzing the main data gained from the research subject, namely the scientists at the universities in Yogyakarta more about 114 which they are gained in a quata way. In the analysis, it is used an $\mathrm{CHI}$ square by using the three category of law culture, namely strong, middle and weak. The result shows that the law culture of scientists on copyright in general are strong enough which is showed by the value indicator and positive behaviour on the Acts of Copyright. It means that in the scientist environment, the Act of Cipyright is well understood, comprehended and held by the scientist in doing their scientific activities. The Acts of Copyright also gives gurantee of justice, exactness and utility for the scientist deal with scientific paper.

\section{Pendahuluan}

Pada bagian Penjelasan Umum UndangUndang Dasar 1945 ditentukan, bahwa Indonesia ialah negara yang berdasar atas hukum (rechtsstaat) dan tidak berdasarkan atas kekuasaan belaka (machtsstaat). Namun demikian, keadaan sistem hukum Indonesia masih menunjukkan adanya ketidak seimbangan antara pelaksanaan fungsi hukum dengan perkembangan substansi dan strukturnya. Jika program kodifikasi dan unifikasi hukum dijadikan ukuran, maka pembangunan struktur dan subtansi hukum telah berjalan cukup baik dan stabil karena dari waktu ke waktu ada peningkatan produktivitas. Akan tetapi, pada sisi lain dapat dilihat adanya fungsi hukum yang cenderung merosot.'. Ketidak sinkronan pertumbuhan antara fungsi, subtansi dan struktur hukum disebabkan adanya faktorfaktor yang tidak dan atau kurang mendukung bekerjanya sistem hukum di Indonesia.

Dari ketentuan GBHN 1999, dapat diketahui bahwa prinsip-prinsip negara hukum Indonesia, dalam tataran praksis ${ }^{2}$ belum

'Moh. Mahfud MD. 2000. Pergulatan Politik dan Hukum di Indonesia. Yogyakarta: Gama Media. HIm. 2-3.

${ }^{2}$ Istilah praksis tidak sama dengan praktik dalam arti umum. Praksis merupakan prilaku sadar yang diyakini kebenarannya dan sarat dengan nilai-nilai yang melatarbelakanginya. Sementara pengertian praktik merupakan prilaku tanpa nilai-nilai yang dipilih secara sadar dan diyakini kebenarannya, periksa Darji Darmodiharjo \& Shidarta. 1996. Penjabaran Nilai-nilai Pancasila dalam Sistem Hukum Indonesia. Jakarta: PT RajaGrafindo. HIm. 187. 
sepenuhnya dapat terwujud. Bahkan telah terjadi krisis hukum di Indonesia, yaitu adanya kemerosotan integritas moral dan profesionalisme aparat hukum, menurunnya kesadaran hukum, buruknya mutu pelayanan, tidak adanya kepastian dan keadilan hukum. Menghadapi kondisi demikian, Bab IV GBHN 1999 telah menggariskan arah kebijakan pembangunan di bidang hukum, yaitu:

1) Mengembangkan budaya hukum di semua lapisan masyarakat untuk terciptanya kesadaran dan kepatuhan hukum dalam kerangka supremasi hukum dan tegaknya negara hukum;

2) Menata sistem hukum nasional yang menyeluruh dan terpadu dengan mengakui dan menghormati hukum agama dan hukum adat serta memperbaharui perundang-undangan warisan kolonial dan hukum nasional yang diskriminatif, termasuk ketidakadilan jender dan ketidaksesuaiannya dengan tuntutan reformasi melalui program legislasi;

3) ...dst

Berdäsarkan arah kebijakan (politik hukum) 'yang terdapat dalam GBHN 1999, dapat diketahui sasaran yang ingin dicapai dalam pembangunan hukum ke depan, yaitu antara lain terwujudnya budaya hukum di semua lapisan masyarakat, yang mewarnai penataan sistem hukum nasional yang menyeluruh dan terpadu, serta penegakan hukum secara konsisten.

Masalah budaya hukum merupakan salah satu agenda reformasi hukum yang harus segera ditangani dan digarap secara serius, di samping aspek-aspek hukum lainnya. Pengalaman masa lalu bangsa Indonesia yang hanya menekankan pada aspek yuridis formal, tanpa menekankan pada pembangunan perilaku hukum dan moralitas hukum masyarakat, bangsa Indonesia telah jatuh ke dalam kesalahan-kesalahan yang serius. ${ }^{3}$ Dengan demikian, pengkajian tentang budaya hukum menjadi hal yang penting dan relevan. Meskipun demikian, kajian budaya hukum (legal culture) ini belum mendapatkan tempat yang memadai dalam kurikulum pengajaran hukum-di Fakultas Hukum. Titik tekan pengajaran hukum masih didominasi oleh penyampaian materi hukum yang berkaitan dengan subtansi dan struktur hukum. Padahal ketiga-tiganya merupakan komponen dari suatu sistem hukum. Materi substansi sistem hukum sudah banyak terkait dengan pengajaran mata kuliah hukum materiil, sedangkan materi struktur hukum banyak terkait dengan pengajaran materi hukum formil (hukum acara). Kajian budaya hukum dalam IImu Hukum termasuk dalam bingkai kajian Ilmu Hukum Empiris. ${ }^{4}$

Beberapa alasan tentang pentingnya kajian masalah budaya hukum ini dapat

'Satjipto Rahardjo. "Keluasan Reformasi Hukum." Kompas. 8 Mei 1998.

${ }^{4} \mathrm{Di}$ sisi lain juga terdapat kajian hukum normatif/ dogmatik. Kajian ini mengkonsepsikan hukum sebagai norma, sedangkan kajian hukum empiris mengkonsepsikan hukum sebagai perilaku nyata yang mempola; periksa, Soetandyo Wignjosoebroto. 1994. "Masalah Metodologik dalam Penelitian Hukum Sehubungan dengan Masalah Keragaman Pendekatan Konseptualnya." Makalah dalam Forum Komunikasi Hasil Penelitian Bidang Hukum. 5-8 Desember 1994. HIm.4-5. 
dikemukakan sebagai berikut: Pertama, hukum yang dinyatakan dalam sumbersumber formal, dalam pelaksanaannya tidak selamanya berjalan sesuai dengan keinginan semula. Nilai-nilai yang terkandung dalam sumber-sumber formal hukum tersebut, kadang-kadang harus berhadapan dengan nilai-nilai atau sistem nilai' yang ada pada individu dan masyarakat yang menjadi sasaran keberlakuan norma hukum tersebut. Kadang-kadang terjadi tarik menarik antara nilai yang berasal dari individu atau masyarakat dan nilai-nilai yang berasal dari norma hukum tersebut. Benturan nilai-nilai tersebut dapat menyebabkan ketegangan antara tuntutan nilai hukum dengan nilai-nilai yang ada di masyarakat. Bila nilai-nilai yang terdapat dalam norma hukum tersebut kalah dan terabaikan akan berakibat hukum tersebut mati atau tidak dapat melakukan fungsinya. Dengan mengkaji budaya hukum dapat diketahui interaksi antara nilai-nilai yang terdapat dalam norma hukum dengan nilai-nilai yang terdapat di masyarakat yang menggambarkan suatu budaya hukum dari masyarakat tersebut ${ }^{5}$. Kedua, pengkajian budaya hukum dapat dipakai dan bermanfaat sebagai sumber informasi untuk menjelaskan sistem hukum secara luas. Hal ini berguna untuk dijadikan alat analisis untuk menjelaskan, mengapa sistem hukum itu tidak dapat dijalankan sebagaimana mestinya atau menjalani pelaksanaan yang berbeda dari pola aslinya. ${ }^{6}$ Pengkajian masalah hukum yang hanya melihat dan menekankan bekerjanya hukum menurut prosedur formal sebagaimana dibagankan dalam peraturan perundangundangan, belum mampu menjelaskan secara lengkap dan: luas bagaimana sesungguhnya masyarakat menyelesaikan masalah-masalah hukum yang dihadapi. Dengan mengkaji budaya hukum, maka dapat diketahui nilai-nilai dan sikap-sikap sosial yang berpengaruh pada bekerjanya norma hukum tersebut. Dengan mengkaji budaya hukum, dapat diketahui penggunaan, ketidakpenggunaan, kesalah-penggunaan, dan penyalahgunaan proses hukum dan sistem hukum. ${ }^{7}$ Ketiga, budaya hukum pada hakikatnya merupakan salah satu komponen yang membentuk suatu sistem hukum. Komponen yang lain adalah subtansi dan struktur hukum. ${ }^{8}$ Karena merupakan salah satu komponen dari suatu sistem hukum, maka keberadaannya menjadi sangat penting dan menentukan. Hilangnya komponen tersebut akan melemahkan dan menghilangkan makna komponen yang lainnya. Friedman mengatakan bahwa budaya hukum berfungsi sebagai bensin motor keadilan. ${ }^{9}$ Lebih lanjut dikatakan: "The legal culture, in other words, is the climate of social thought and social force

${ }^{5}$ Darji Darmodiharjo dan Sidarta. 1996. Penjabaran Nilai-Nilai Pancasila dalam Sistem Hukum Indonesia. Jakarta: PT Raja Grafindo. HIm. 153.

'Satjipto Rahardjo. 1991. Ilmu Hukum. Cetakan III. Bandung: PT Citra Aditya Bakti. HIm.155.

'Satjipto Rahardjo. 1980. Hukum dan Masyarakat. Bandung: Angkasa. Hlm. 85.

${ }^{8}$ Lawrence M. Friedman. 1975. The Legal System : A Social Science Perspective. New York: Russe! Sage Fondation. Him.11-16.

${ }^{9} \mathrm{lbid}$. Hlm 193-194. 
which determines how law is used, avoided, or abused. Without legal culture, the legal system is inert - a dead fish lying in a basket, not a living fish swimming in its sea". ${ }^{10}$ Menurut Friedman, sebagaimana dikutip oleh Rahardjo, bahwa komponen budaya hukum merupakan komponen yang terdiri dari nilainilai dan sikap-sikap yang merupakan pengikat sistem serta menentukan tempat sistem hukum itu di tengah-tengah kultur bangsa secara keseluruhan." Aspek kultural ini sangat diperlukan dalam memahami nilainilai budaya yang hidup di masyarakat berkaitan dengan sistem hukumnya. Dengan demikian, péngkajian budaya hukum lebih memperluas dan menambah lengkap kajian sistem hukum. Keempat, pada hakikatnya hukum merupakan kaidah yang sarat dengan nilai-nilai, akan tetapi hukum tidak dapat merealisasikan sendiri nilai-nilai yang menjadi kehendaknya, karena hukum hanyalah kaidah. Hukum membutuhkan kehadiran manusia untuk mewujudkannya. Dengan mengkaji. budaya hukum dapat diketahui bagaimana perilaku manusia dalam mewujudkan nilainilai hukum dalam kenyataannya terutama berkaitan dengan faktor mentalitas atau perilaku budayanya, yaitu bagaimana ia memaknai tentang hakikat hukum itu.

Dari pemaparan tentang pentingnya mengkaji budaya hukum di atas, tulisan ini mengangkat topik tentang budaya hukum. Studi ini akan menjadikan peraturan perundang-undangan di bidang Hak Cipta sebagai kasus. Pemilihan topik penelitian ini dilatarbelakangi oleh munculnya isu-isu yang berkaitan dengan permasalahan hak cipta di Indonesia, antara lain: Pertama, disinyalir bahwa masyarakat Indonesia dalam konteks pergaulan internasional dikenal sebagai masyarakat yang kurang menghargai hak cipta $^{12}$. Kedua, hak cipta merupakan hak eksklusif (khusus), yang mana bila dilihat dari akar budaya bangsa Indonesia, dapat dikatakan tidak mempunyai akar dalam kebudayaan Indonesia dan juga tidak terdapat dalam sistem hukum adat ${ }^{13}$. Nilai-nilai falsafah yang mendasari pemilikan individu terhadap suatu karya cipta manusia baik dalam bidang ilmu, sastra, maupun seni adalah nilai budaya barat yang menjelma dalam sistem hukumnya. ${ }^{14}$ Dikarenakan hak cipta tersebut bukan berasal dari nilai-nilai budaya bangsa Indonesia, tetapi nilai-nilai barat yang menjelma dalam sistem hukum keperdataannya, kadangkala pemberlakuan hak tersebut dalam kehidupan masyarakat menimbulkan pertentangan dengan nilaj-nilai budaya tradisional yang telah melembaga dalam kehidupan masyarakat. Artinya, ada perbuatan yang dikualifikasikan sebagai pelanggaran hak cipta menurut ketentuan

10Lawrence M.Friedmen. 1986. American Law. New York:W.W.Nortón \& Co. HIm. 7.

"Satjipto Rahardjo. Hukum dan... Op.Cit. HIm.84.

12Periksa Republika 9 Januari 1999.

${ }^{13}$ yaitu hukum Indonesia asli yang tidak tertulis dalam bentuk perundang-undangan Rl yang di sana-sini mengandung unsur agama, periksa, Hilman Hadikusuma. 1992. Pengantar IImu Hukum Adat Indonesia. Bandung: CV Mandar Maju. HIm. 32.

${ }^{14}$ Salman Luthan. 1989. "Delik Hak Cipta." Makalah Diskusi Jurusan Hukum Pidana FH UII. 24 Agustus 1989. HIm. 36. 
undang-undang, akan tetapi dalam nilai-nilai budaya masyarakat tersebut tidak dianggap sebagai suatu pelanggaran hak cipta. ${ }^{15}$ Demikian juga tentang konsep yang menyangkut perlindungan hak cipta bukan merupakan ide yang dimiliki bangsa Indonesia. ${ }^{16}$ Ketiga, realitas di masyarakat masih menunjukkan banyaknya pelanggaran hak cipta dan disinyalir telah mencapai tingkat yang membahayakan dan dapat merusak tatanan kehidupan masyarakat pada umumnya terutama kreativitas untuk mencipta. ${ }^{17} \mathrm{Di}$ sisi lain usaha yang dilakukan oleh pemerintah Indonesia dalam rangka perlindungan terhadap karya cipta ternyata belum membuahkan hasil yang maksimal, meskipun UU Hak Cipta dalam memberikan perlindungan hukum terhadap suatu karya cipta maupun terhadap hak dan kepentingan pencipta dan pemegang hak cipta sudah cukup memadai bahkan dapat dikatakan berlebihan. Realitanya, pelanggaran hak cipta masih terus menggejala dan seolah-olah tidak dapat ditangani oleh aparat penegak hukum. Berbagai macam pelanggaran terus berlangsung seperti pembajakan terhadap karya cipta, mengumumkan, mengedarkan maupun menjual karya cipta orang lain tainpa seizin pencipta atau pemegang hak cipta. ${ }^{18}$ Keempat, meskipun kelemahan-kelemahan dalam subtansi maupun struktur hukum telah mengalami perbaikan dari waktu ke waktu, namun aspek budaya hukum UU Hak. Cipta belum mendapatkan perhatian yang serius. Undang-Undang itu akan bekerja dengan baik jika budaya hukum masyarakatnya mendukung, yaitu dari budaya mengabaikan hak-hak individual atas hak cipta, berubah ke budaya menghormati hak cipta.

Sebagaimana diketahui bahwa subyek hukum atau para pelaku hukum yang terkait secara langsung terhadap keberlakuan UU Hak Cipta adalah para ilmuwan, sastrawan dan seniman, sedangkan yang terkait secara tidak langsung adalah masyarakat dan pemerintah. Lingkup penelitian ini hanya dibatasi pada meneliti bekerjanya UU Hak Cipta di lingkungan ilmuwan saja. Para ilmuwań dalam melaksanakan kegiatan ilmiahnya dituntut untuk mengindahkan dan menaati norma-norma yang terdapat dalam etika keilmuan (akademis) maupun normanorma hukum yang terdapat dalam UU Hak Cipta. Dalam menghasilkan karya-karya ilmiahnya terkadang terjadi sebuah 'pencurian' gagasan atau ide yang kemudian diklaim sebagai karya sendiri. Kasus 'Ipong S. Azhar' di UGM yang dianggap plagiat karya ilmiah orang lain dalam menyusun disertasi dapat ditunjuk sebagai contoh. ${ }^{19}$ Demikian juga kasus disertasi Yahya Muhaimin tentang Bisnis dan Politik, Kebijaksanaan Ekonomi

\section{${ }^{15} /$ bid.}

${ }^{16}$ Saidin. 1995. Aspek Hukum Hak kekayaan Intelektual (Intellectual Property Right). Jakarta: PT Raja Grafindo Persada. Hlm. 27.

${ }^{17}$ Sophar Maru Hutagalung. 1994. Hak Cipta Kedudukan dan Peranannya di dalam Pembangunan. Jakarta: Akademi Pressindo. HIm. 2.

${ }^{18} / \mathrm{bid}$.

${ }^{19 B}$ Baca Kompas 28 Desember 1999. 
Indonesia 1950-1980 dianggap sebagai karya plagiat karena banyak kutipan-kutipan di dalamnya yang mengambil atau mengutip karya orang lain tanpa menyebut sumbernya secara jelas. ${ }^{20}$ Dengan demikian, para ilmuwan (dosen) dalam melakukan kegiatan keilmuannya juga tidak dapat lepas dari tanggungjawab keilmuan baik secara etis maupun yuridis. Tanggungjawab etis adalah tanggungjawab ilmuwan yang berkaitan dengan pelanggaran etika keilmuan, sedangkan tanggungjawab yuridis adalah tanggungjawab ilmuwan yang berkaitan dengan pelanggaran hukum yaitu UU No.12 Tahun 1997 tentang Hak Cipta.

\section{Tinjauan Teoritis tentang Budaya Hukum}

Istilah budaya hukum pertama-tama dikemukakan oleh Friedman untuk menyebut kekuatan-kekuatan sosial (social forces) yang mempengaruhi bekerjanya sistem hukum di masyarakat, yang berupa elemen-elemen nilai dan sikap masyarakat berhubungan dengan institusi hukum. Dikemukakan oleh Friedman bahwa: ${ }^{21}$

Social forces are constantly at work on the law -destroying here, renewing there; inigorating here, deadening there; choosing what parts of "law" will oprerate, which part will not, what subtitute, detours, and bypasses will spring up; what changes will take place openly or secretly. For want of a better term, we can call some of these forces the legal culture. It is the element of social attitude and value.

Lebih lanjut dikemukakan bahwa istilah budaya hukum mengacu pada pengetahuan publik, sikap dan pola perilaku masyarakat berkaitan dengan sistem hukum:22

The term legal culture has been loosly used to discribe a number of related phenomena. It refers to public knowlege of and attitudes and behavior patterns toward the legal system. Do people feel and act as if courts are fair? When are they willing to use courts? What part of the law do they consider legitimate? What do they know about the law in general? These attitudes differ from person to person, but one can also speak of the legal culture of a country or a group, if there are patterns that distinguish it from the culture of the countries or groups..."

Friedman, sebagaimana dikemukakan oleh Soekanto, menelaah budaya hukum dari pelbagai perspektif. la menganalisa budaya hukum nasional yang dibedakan dari subbudaya hukum yang berpengaruh secara positif atau negatif terhadap hukum nasional. la juga membedakan budaya hukum internal

${ }^{20}$ Moh. Mahfud MD. 1999, "Pewadahan Etika Keilmuan di dalam UU Hak Cipta." Jumal Hukum No. 12 Vol. 6 1999. Hlm. 31. Periksa juga Ismet Fanani. 1992. Plagiat-Plagiat di MIT, Tragedi Akademis di Indonesia. Jakarta: CV Haji Masagung.

${ }^{21}$ Lihat Lawrence M.Friedman. "The Legal System:..." Op.Cit. HIm. 15.

22/bid. Hlm.193-194. 
dan budaya hukum eksternal. Budaya hukum internal merupakan budaya hukum warga masyarakat yang melaksanakan tugas-tugas hukum secara khusus, seperti polisi, jaksa hakim dalam menjalankan tugasnya, sedangkan budaya hukum eksternal merupakan budaya hukum masyarakat pada ùmumnya, misainya bagaimana sikap dan pengetahuan masyarakat terhadap ketentuan perpajakan dan perceraian. la juga membedakan budaya hukum tradisional dan budaya hukum modern. Dengan adanya pelbagai sistem hukum dalam suatu komunitas politik tunggal, maka disebut pluralisme hukum. Pluralisme hukum dapat berbentuk horizontal atau vertikal. Pada yang horisontal masing-masing subsistem atau subbudaya mempunyai kekuatan hukum sama, sedangkan yang vertikal kekuatan hukumnya berbeda-beda. Menurut Friedman, budaya hukum menunjuk pada dua hal yaitu : (1) unsur adat-istiadat yang organis berkaitan dengan kebudayaan secara menyeluruh; dan (2) unsur nilai dan sikap sosial. Lebih lanjut dikatakan bahwa sistem hukum yang terdiri dari struktur dan subtansi, bukanlah merupakan mesin yang bekerja. Apabila kedua unsur itu berfungsi dalam masukan dan keluaran proses hukum, maka kekuatan-kekuatan sosial tertentu berpengaruh terhadapnya. Kekuatan-kekuatan sosial itu merupakan variabel tersendiri yang disebut 'budaya hukum'. Variabel itu berproses bersamaan dengan kebudayaan sebagai suatu variasi, yang kemungkinan variabel tersebut menentang, melemahkan, atau memperkuat sistem hukum. ${ }^{23}$

Menurut Friedman, budaya hukum itu mengacu kepada bagian-bagian dari budaya pada umumnya yang berupa kebiasaan, pendapat, cara-cara berprilaku dan berpikir yang mendukung atau menghindari hukum.

The legal culture refers, then, to those parts of general culture-customs, opinions, ways of doing and thinking - that bend social forces toward or away from the law and in partikulary ways. The term rougly describes attitudes about law, more or less analogous to the political culture, which Almond and Verba defined as the "political system as internalized in the cognitions, feelings, and evaluations of its population". The basic notion is that of values and attitudes which, when transled in to demands, start the machinery of the legal system moving or, conversely, stop in its tracks. ${ }^{24}$

Menurut Soekanto, budaya hukum merupakan budaya non-material atau spiritual. Inti budaya hukum sebagai budaya non-material atau spiritual adalah nilai-nilai yang merupakan konsepsi-konsepsi abstrak mengenai apa yang baik (sehingga harus

\footnotetext{
${ }^{23}$ Soerjono Soekanto, et.al. 1988. Disiplin Hukum dan Disiplin Sosial. Jakarta: Rajawali Press. Him. 166-167.

${ }^{24}$ Lawrence M.Friedman. "The Legal System:..." Op.Cit. HIm. 15-16; periksa juga Gabriel Almond and Sidney Verba. 1963. The Civic Culture. HIm.14. The term "legal culture" can also be used in an anthropological sense -those traits of behavior and attitude that make the law of one community different from that of another, that make the law of Eskimos diffrent from French law, ancient Roman law, and the law of the Cambodians. The term can be used in a slightly different way to discribe underlying traits of a whole legal system -its ruling ideas, its flavor, its style.
} 
dianuti) dan apa yang buruk (sehingga harus dihindari). Nilai-nilai tersebut merupakan dasar dari etika (mengenai apa yang benar dan yang salah), norma atau kaidah (yang berisikan suruhan, larangan atau kebolehan), dan pola perilaku manusia. Nilai-nilai tersebut paling sedikit mempunyai 3 (tiga) aspek, yaitu aspek kognitif, aspek afektif, dan aspek konatif. Aspek kognitif adalah aspek yang berkaitan dengan rasio atau pikiran, aspek afektif adalah aspek yang berkaitan dengan perasaan atau emosi, sedangkan aspek konatif adalah aspek yang berkaitan dengan kehendak untuk berbuat atau tidak berbuat. ${ }^{25}$

Menurut Darmodiharjo dan Shidarta, budaya hukum identik dengan pengertian kesadaran hukum, yaitu kesadaran hukum dari subyek hukum secara keseluruhan. Mengutip pendapat Hartono yang diambil dari pendapat ahli hukum Belanda Scmid, mereka membedakan antara perasaan hukum (rechtsgevoel) dengan kesadaran hukum (rechtsbewutzijn). Penilaian masyarakat yang timbul secara spontan merupakan perasaan hukum, sedangkan kesadaran hukum adalah abstraksi mengenai perasaan hukum dari suatu subyek hukum. Subyek hukum tersebut dapat berupa individu, sekelompok individu (masyarakat) dan juga badan hukum tertentu. ${ }^{26}$ Sementara itu Soekanto dan Taneko mengemukakan bahwa kesadaran hukum berkaitan dengan nilai-nilai, yaitu konsepsikonsepsi abstrak di dalam diri manusia tentang keserasian antara ketertiban dengan ketentraman yang dikehendaki atau yang sepantasnya. Indikator-indikator kesadaran hukum tersebut adalah sebagai berikut: ${ }^{27}$

a) pengetahuan tentang peraturan-peraturan hukum (law awareness);

b) pengetahuan tentang isi peraturan hukum (law acquaintance);

c) sikap terhadap peraturan-peraturan hukum (legal attitude);

d) pola perilaku hukum (legal behavior).

Konsep budaya hukum tersebut pernah dipergunakan oleh Lev sebagai kerangka analisis untuk menjelaskan pola-pola perubahan sistem hukum Indonesia semenjak revolusi. la menaruh perhatiannya untuk mencari kejelasan mengapa dan bagaimana fungsi-fungsi hukum di wilayah jajahan dilayani oleh lembaga-lembaga yang berbeda dengan hukum di negara yang merdeka. Dengan perspektif tersebut, Lev ingin mengetahui tempat lembaga-lembaga hukum tersebut di dalam masyarakat dan negara Indonesia. ${ }^{28}$ Uraian Lev berkisar pada dua konsep, yaitu sistem hukum dan budaya hukum. Sistem hukum menekankan kepada prosedur, akan tetapi konsep ini tidak mampu

${ }^{25}$ Soerjono Soekanto, et al. 1994. Antropologi Hukum, Proses Pengembangan Ilmu Hukum Adat, Jakarta: CV Rajawali. HIm 202-203.

${ }^{26}$ Periksa Darji Darmodiharjo dan Shidarta. Op.Cit. HIm. 154-155.

${ }^{27}$ Soerjono Soekanto dan Soleman B. Taneko. 1983. Hukum Adat Indonesia. Jakarta: Penerbit Rajawali. HIm., 348.

29Periksa, Daniel S. Lev. 1990. Hukum dan Politik di Indonesia, Kesinambungan dan Perubahan. Terjemahan Nirwono dan AE Priyono. Jakarta: LP3ES. 
menjelaskan bagaimana sesungguhnya orangorang menyelesaikan masalahnya di dalam kehidupan sehari-hari. Untuk dapat menjelaskan masalahnya, maka sistem hukum itu dalam menjalankan fungsinya membagi pekerjaannya dengan lembagalembaga lain di dalam masyarakat. Suatu sistem hukum tersebut terdiri atas prosesproses formal yang membentuk lembagalembaga formal bersama-sama dengan proses informal yang mengelilinginya. Pengorganisasian, tradisi, dan gaya sistem politik yang terdapat pada bangsa sangat menentukan seberapa jauh proses-proses hukum itu atau dapat digunakan dalam rangka manajemen sosial serta usaha mencapai tujuan-tujuan bersama. Konsep yang kedua adalah konsep budaya hukum. Budaya hukum diartikan sebagai nilai-nilai yang terkait dengan hukum (subtantif) dan proses hukum (hukum ajektif). Budaya hukum mencakup dua komponen pokok yang saling berkaitan, yakni nilai-nilai hukum subtantif dan nilai-nilai hukum ajektif (prosedural). Nilai-nilai hukum subtantif berisikan asumsi-asumsi fundamental mengenai distribusi dan penggunaan sumber-sumber di dalam masyarakat, apa yang secara sosial dianggap benar atau salah, dan seterusnya. Nilai-nilai hukum ajektif mencakup sarana-sarana pengaturan sosial maupun pengelolaan konflik yang terjadi di dalam masyarakat. ${ }^{29}$

Dari uraian tersebut dapat diketahui bahwa istilah budaya hukum diperkenalkan oleh Friedman untuk menunjukkan suatu kekuatan sosial yang ikut menentukan terhadap bekerjanya sebuah sistem hukum. Faktor sosial tersebut berproses bersamaan dengan bekerjanya sistem hukum dalam sebuah konteks kebudayaan. Faktor sosial tersebut dapat mendukung atau menghambat bekerjanya sistem hukum, hal itu bergantung pada unsur adat-istiadat, nilai dan sikap masyarakat berkaitan dengan hukum. Budaya hukum merupakan salah satu komponen dari sistem hukum di samping komponen struktur dan substansi hukum. Komponen budaya hukum merupakan variabel penting dalam sistem hukum karena dapat menentukan bekerjanya sistem hukum. Budaya hukum merupakan sikap dan nilai-nilai dari individuindividu dan kelompok-kelompok masyarakat yang mempunyai kepentingan-kepentingan (interests) yang kemudian diproses menjadi tuntutan-tuntutan (demands) berkaitan dengan hukum. Kepentingan dan tuntutan tersebut merupakan kekuatan sosial yang sangat menentukan berjalan atau tidaknya sistem hukum.

Dari konsep budaya hukum sebagaimana telah dikemukakan di atas, dapat diketahui aspek-aspek yang terkandung dalam konsep budaya hukum. Menurut penulis berdasarkan unsur-unsur yang terkandung dalam konsep budaya hukum setidak-tidaknya terdapat dua aspek dalam konsep budaya hukum yaitu aspek nilai (value) dan sikap (attitude). Kedua aspek tersebut terjalin secara erat dan menentukan satu dengan lainnya, artinya aspek nilai yang dianut oleh seseorang atau kelompok orang akan sangat menentukan sikap seseorang atau kelompok orang

${ }^{29}$ Daniel S. Lev.Op.Cit. HIm. 119-120. Dan juga periksa Satjpto Rahardjo. "Hukum dan..." Op.Cit. HIm. 87. 
tersebut. Kedua aspek itu merupakan indikator dari budaya hukum, artinya dengan mengetahui nilai dan-sikap masyarakat terhadap hukum maka akan dapat diketahui keadaan budaya hukum dari masyarakat tersebut.

\section{Nilai dan Sikap sebagai Indikator Budaya Hukum}

Nilai dan sikap mempunyai hubungan yang sangat erat, bahkan kedua konsep tersebut seringkali digunakan bersamaan dalam definisi-definisi sikap. Sebenarnya kedua istilah tersebut tidak sama persis maknanya. Menurut Feisbein, dikutip oleh Adisubrata, orientasi nilai seseorang tercermin dalam sikapnya, oleh karena itu untuk mengetahui orientasi nilai seseorang maka harus mengungkap sikap orang tersebut terhadap berbagai obyek yang dihadapi. Dengan mengetahui sikap maka akan diketahui pula tendensi untuk berbuat atau bereaksi dalam situasi tertentu bila seseorang dihadapkan pada stimulus tertentu. ${ }^{30}$ Demikian halnya untuk mengungkap orientasi nilai hukum berarti harus mengungkap pula sikap masyarakat terhadap hukum. Dengan mengetahui sikap masyarakat terhadap hukum maka akan diketahui tendensi dan reaksi masyarakat terhadap hukum, sehingga dapat diketahui efektif tidaknya hukum dan juga ditaati tidaknya aturan hukum di masyarakat.

Mengetahui nilai juga mempunyai arti yang penting, karena nilai merupakan standar bagi sikap dan perbuatan. Nilai merupakan keyakinan tunggal yang menentukan dan mengarahkan terbentuknya sikap ke dalam bentuk tingkah laku. Dengan mengetahui nilai akan dapat diketahui keyakinan, pandangan, standar, dan arah ke mana sikap dan perbuatan masyarakat, apakah sudah sesuai dengan yang diharapkan atau belum: ${ }^{31}$

Menurut Radbruch, terdapat tiga elemen nilai-nilai hukum yaitu keadilan, kemanfaatan, dan kepastian hukum. Hukum sebagai konsep kultural, yaitu konsep yang berhubungan dengan nilai-nilai (hukum), sesuai dengan maksudnya, hukum merupakan sesuatu yang dimaksudkan untuk mewujudkan cita-cita hukum. Cita-cita hukum itu dapat ditemukan dalam keadilan. Namun karena dalam kenyataan sulit untuk mencari pedoman yang digunakan untuk menentukan isi keadilan tersebut, maka di dalam keadilan itu ditambahkan elemen kedua yaitu kemanfaatan atau kesesuaian dengan tujuan. Akan tetapi permasalahan tujuan dan kemanfaatan tidak dapat dijawab secara tegas, tapi hanya bersifat relatif. Hukum sebagai suatu tatanan kehidupan bersama tidak dapat didasarkan pada perbedaan-perbedaan pandangan individu (yang relatif), akan tetapi harus merupakan tatanan yang harus disepakati bersama. Oleh karena itu perlu adanya elemen ketiga yaitu kepastian hukum. Kepastian hukum mensyaratkan hukum harus bersifat positif dan positivitas hukum itu menjadi prasyarat suatu kebenaran. Posivitas hukum dapat ditemukan dalam konsep hukum yang

${ }^{30}$ Dalil Adisubroto. "Orientasi Nilai-nilai Orang Jawa serta Ciri-Ciri Kepribadiannya." Disertasi. Universitas Gadjah Mada. Yogyakarta 1987. HIm. 57.

${ }^{31}$ Rokeach. 1978. The Natural of Human Values. New York: The Free Press. HIm. 18-19. 
benar sebagaimana kebenaran isinya menjadi tugas hukum positip. ${ }^{32}$

Menurut Radbruch, di antara ketiga nilai hukum tersebut, yaitu nilai-keadilan, kemanfaatan, dan kepastian hukum, terjadi ketegangan atau ketidak serasian karena masing-masing mempunyai tuntutan sendiri yang berbeda-beda. Tuntutan bagi nilai kepastian hukum yang utama adalah adanya peraturan hukum. Apakah peraturan tersebut adil atau tidak dan mempunyai kemanfaatan atau tidak adalah di luar nilai kepastian hukum. Untuk mengatasi ketegangan / ketidakserasian tersebut dilakukan pembagian secara langsung bidang-bidang operasinya di antara ketiga nilai tersebut. Untuk keadilan dilakukan pengujian apakah sebuah aturan tersebut memiliki sifat hukum atau tidak. Untuk. Kemanfaatan ditentukan apakah isinya mengandung kebenaran, dan untuk kepastian hukum ditentukan apakah memilki validitas atau tidak. Radbruch menyimpulkan bahwa ketiga nilai tersebut secara bersama-sama mengatur hukum di semua aspek walaupun mungkin saling bertentangan satu sama lain. Hal tersebut tergantung pada penekananpenekanan yang diutamakan pada ketiga nilai hukum tersebut. ${ }^{33} \mathrm{Hal}$ senada dikemukakan oleh Rahardjo, bahwa adanya pertentangan I ketidakserasian nilai-nilai hukum tersebut karena masing-masing mempunyai tuntutan yang berbeda-beda sehingga penilaian masyarakat tentang hukum pun bermacammacam. Penilaian hukum dalam masyarakat dapat bergantung dari tuntutan masingmasing nilai hukum tersebut. Apa yang sudah dinilai sah menurut persyaratan yang harus dipenuhi oleh suatu peraturan, dapat dinilai tidak sah dari segi kemanfaatan dan rasa keadilan dari masyarakat. Demikian juga dapat terjadi sebaliknya. ${ }^{34}$

Konkritisasi nilai adalah norma, termasuk dalam hal ini adalah norma hukum. Norma hukum tersebut kemudian membentuk suatu tatanan yang harmonis dalam suatu sistem hukum, yang berfungsi sebagai sistem kontrol sosial, sarana penyelesaian konflik, dan sebagai sarana pembaharuan masyarakat. Norma hukum yang diwujudkan dalam tindakan konkrit disebut perilaku hukum. Perilaku hukum ini dapat dikatakan sebagai praksis dari nilai-nilai di belakangnya, yaitu nilai-nilai yang melatarbelakanginya. ${ }^{35}$

Soebijanta, yang dikutip oleh Noraha menyatakan bahwa nilai hanya dapat dipahami jika dikaitkan dengan sikap dan tingkah laku dalam sebuah model metodologis sebagaimana gambar berikut: ${ }^{36}$

\section{Nilai $\longrightarrow$ Sikap $\longrightarrow$ Tingkah Laku}

Skema keterkaitan nilai, sikap dan tingkah laku

${ }^{32}$ Gustav Radbruch. 1950. The Legal Philosophies of Lask, Radbruch, and Dabin. Cambridge. Massachusetts: Harvard University Press. HIm.107-108.

33/bid. HIm. 110-111.

${ }^{34}$ Satjipto Rahardjo. "Ilmu ...." Op.Cit. HIm. 19.

${ }^{35}$ Darji Darmodiharjo dan Shidarta. Op.Cit. HIm. 187.

${ }^{36}$ Taziduhu Ndraha. 1997. Budaya Organisasi. Jakarta: PT Rineka Cipta. HIm. 18. 
Dari uraian di atas dapat diketahui bahwa sikap merupakan cermin dari nilai-nilai seseorang atau masyarakat terhadap apa yang diyakini atau dipegangi. Dengan mengetahui sikap maka akan dapat diketahui pandangan, keyakinan dan harapan-harapan masyarakat. Dengan mengetahui sikap maka dapat pula diketahui kecenderungan perilaku masyarakat tentang sesuatu hal. Demikian halnya dengan perilaku hukum masyarakat maka dapat diketahui pula dengan menggunakan konsep sikap tersebut.

Sikap mengandung pengertian yang bermacam-macam. Pada intinya para ahli sepakat bahwa sikap berbeda dengan perilaku. Sikap masih berupa kecenderungan untuk berperilaku. Allport, dikutip oleh Assael, menegaskan bahwa sikap adalah keadaan (predisposisi) yang dipelajari untuk menghadapi atau merespon objek serta situasi tertentu dan secara konsisten menuju pada arah yang mendukung (favourable) ataupun menolak (unfavourable). Allport, juga dikutip oleh Assael mengatakan sikap merupakan kesiapan untuk bereaksi terhadap sesuatu objek dengan cara-cara tertentu. ${ }^{37}$

Menurut Berkowitz, dikutip oleh Azwar, sikap seseorang terhadap objek adalah perasaan mendukung atau memihak ataupun perasaan tidak mendukung objek tersebut. Thurstone dan Osgood, dikutip oleh Azwar, mengatakan bahwa sikap adalah bentuk evaluasi atau reaksi perasaan. Reaksi ini didasarkan pada proses evaluasi dalam diri individu yang akan memberikan kesimpulan nilai baik atau buruk, suka atau tidak suka, senang atau tidak senang dan akan bermuara pada konsep reaksi terhadap objek sikap.?

Sikap bersifat dinamis dan terbuka terhadap kemungkinan perubahan karena terjadinya interaksi individu-individu dengan lingkungan sekitar. Sikap baru akan berarti bila dinyatakan dalam bentuk perilaku lisan atau perbuatan. Walaupun demikian, potensi reaksi yang dinyatakan secara konsisten bila individu dihadapkan pada stimulus sikap, hal tersebut sangat tergantung pada kondisi serta situasi di mana individu berada pada saat harus mengekspresikan sikapnya. Salah satu karakteristik reaksi perilaku manusia adalah bersifat diferensial, artinya suatu stimulus yang sama belum tentu menimbulkan reaksi yang sama, dan sebaliknya reaksi yang sama belum tentu ditimbulkan oleh stimulus yang sama.

Sax, yang dikutip oleh Azwar, menunjukkan beberapa karakteristik sikap yang meliputi arah, intensitas, keluasan, konsistensi, dan spontanitas. Karakteristik arah menunjukkan apakah individu menyetujui atau tidak menyetujui, mendukung atau tidak mendukung, memihak atau tidak memihak terhadap suatu objek sikap. Intensitas menunjukkan kekuatan sikap terhadap objek. Pengertian keluasan menunjukkan luastidaknya cakupan objek sikap yang disetujui atau tidak disetujui oleh individu. Konsistensi

${ }^{37}$ Assael, H. 1984. Consumer Behavior and Marketing Action. Second Edition. Boston: Kent Publishing. HIm. 12.

${ }^{38}$ Saifudin Azwar. 1995. Sikap Manusia Teori dan Pengukurannya. Edisi ke 2. Yogyakrta: Pustaka Pelajar. HIm. 5. 
sikap ditunjukkan oleh kesesuaian antara pernyataan sikap yang dikemukakan oleh individu dengan responnya terhadap objek sikap. Spontanitas mengungkapkan sejauh mana kesiapan subjek untuk menyatakan sikapnya secara spontan ${ }^{39}$

Pengukuran terhadap sikap, pernyataanpernyataan sikap secara tertulis merupakan jawaban subjek terhadap stimulus yang ada pada suatu skala sikap dan menjadi indikator utama sikap subjek. Kelompok yang berorientasi pada teori kognitif mendefinisikan sikap sebagai konstelasi komponen kognitif, afektif, dan konatif yang berorientasi dalam memahami, merasakan, dan berperilaku terhadap suatu objek.

Sears, mendeskripsikan aspek-aspek dalam sikap terdiri dari tiga komponen sikap, yaitu: (1) Komponen kognitif (pengetahuan). Komponen ini terdiri dari seluruh sistem kognitif yang dimiliki seseorang mengenai sikap objek tertentu, fakta, pengetahuan, dan keyakinan tentang objek. Dengan demikian, komponen kognitif adalah sejauhmana pengenalan individu terhadap objek yang akan membawa keyakinan tertentu terhadap objek tersebut. (2) Komponen afektif (perasaan). Komponen ini terdiri atas perasaan atau sistem emosi terhadap objek, terutama penilaian. Dengan demikian, ada kaitan erat antara objek dengan sistem emosi. Hubungan emosi dengan sikap bersifat evaluatif, sehingga menentukan arah komponen sikap yang lain. Berbeda dengan sistem kognitif, emosi lebih menekankan faktor perasaan bukan faktor pengetahuan. (3) Komponen konatif (kecenderungan perilaku). Komponen ini terdiri atas kesiapan seseorang untuk bereaksi atau kecenderungan untuk bertindak terhadap objek. Komponen ini dapat berupa verbal, yaitu apa yang diucapkan oleh individu dan dapat pula bersifat non verbal, yaitu yang benar-benar dilakukan individu. ${ }^{40}$

Sikap bersifat dinamis, sehingga proses belajar dan sosialisasi individu mempengaruhi konsistensi sikap. Katz, dikutip oleh Azwar, mengatakan bahwa ada 4 (empat) macam fungsi sikap, yaitu: (1) Fungsi pernyataan nilai. Sikap bertindak sebagai indikator keinginan individu untuk memperoleh kepuasan dalam menyatakan nilai yang dianut sesuai dengan penilaian pribadi dan konsep diri; (2) Fungsi pengetahuan. Sikap merupakan manifestasi dorongan keingintahuan individu mencari penalaran, dan mengorganisasikan pengamatan; (3) Fungsi pertahanan ego. Sikap menjadi pertanda bagi individu yang ingin menghindarkan diri serta melindungi dari hal-hal yang mengancam ego. Bila individu mengetahui fakta dan kebenaran, sikap berfungsi pula sebagai mekanisme pertahanan ego agar individu terhindar dari pengalaman yang tidak menyenangkan; (4) Fungsi instrumental. Ini adalah fungsi manfaat dari sikap. Individu akan memaksimalkan hal: hal yang diinginkan, dan menghindari sama sekali hal-hal yang tidak disukai. Sikap positif akan terbentuk bila individu menganggap sesuatu menguntungkan diri, sementara itu ia akan memberikan sikap negatif bila hal tertentu tersebut menjadikan individu mengalami sejumlah kerugian. ${ }^{41}$

\footnotetext{
$39 /$ bid. HIm. 5.

${ }^{40}$ Sears, et.al. 1988. Psikologi Sosial Jilidl. Terjemah. Jakarta : Erlangga. Hlm.21.

"Saifudin Azwar. Op.Cit. HIm. 53-54.
} 
Demikian halnya dengan sikap orang atau masyarakat terhadap hukum dapat berbentuk positip dan negatip. Sikap positip ditunjukkan oleh perilaku menerima atau mendukung terhadap aturan-atauran atau norma-norma hukum yang diberlakukan, sedangkan sikap negatip ditunjukkan oleh perilaku menolak atau tidak mendukung terhadap aturan-aturan atau norma-norma hukum yang diberlakukan. Mengetahui sikap orang atau masyarakat terhadap hukum mempunyai arti penting karena tercapainya tujuan hukum sangat ditentukan oleh sikap orang atau masyarakat terhadap hukum. Semakin positip sikap masyarakat terhadap hukum maka akan semakin mendukung tercapainya tujuan hukum tersebut dalam mengatur masyarakat. Semakin negatip sikap masyarakat terhadap hukum maka akan semakin menjauhkan tujuan hukum tersebut dalam mengatur masyarakat.

\section{Tiga Kategori Budaya Hukum: Kuat, Sedang, Lemah}

Menurut Ndraha, mengutip Sathe dan Robbins, suatu budaya dapat diukur dari kuatlemahnya budaya tersebut. Jadi ada budaya kuat dan ada budaya lemah. Budaya kuat adalah budaya yang ideal. Menurut Ndraha, mengutip Sathe, tiga ciri khas budaya kuat adalah thickness, extent of sharing, dan clarity ordering. Demikian juga Robbins mengatakan bahwa a. strong culture is characterized by the organization's core values being intensely held, clearly ordered, and widely shared. Jadi budaya kuat adalah yang dipegang semakin intensif (semakin mendasar dan kukuh), semakin luas dianut, dan semakin jelas disosialisasikan dan diwariskan. Semakin kuat budaya, semakin kuat efek atau pengaruh terhadap lingkungan dan perilaku manusia. Budaya kuat juga dapat dikatakan budaya yang berketahanana ${ }^{42}$ Lebih lanjut dikemukakan oleh Ndraha bahwa jika tingkat budaya dihubungkan dengan nilai, dapat diidentifikasi menurut kuantitas dan kualitas sharing suatu nilai di dalam masyarakat, yaitu: pertama, semakin banyak anggota masyarakat (aspek kuantitatif) yang menganut, memiliki dan menaati suatu nilai, semakin tinggi tingkat budayanya. Dilihat dari sudut ini, maka ada budaya global, budaya regional, budaya bangsa, budaya daerah, dan budaya setempat. Kedua, semakin mendasar penaatan nilai (aspek kualitatif), semakin kuat budayanya. Dilihat dari sudut ini, maka budaya dapat dikelompokkan menjadi budaya kuat, budaya sedang, dan budaya lemah. ${ }^{43}$

Dengan mengikuti pendapat Sathe dan Robbins, yang dikutip oleh Ndraha, tentang pembagian budaya menjadi kuat, sedang, dan lemah penulis akan mengikuti pembagian budaya tersebut untuk budaya hukum. Jadi menurut penulis terdapat budaya hukum kuat, sedang dan lemah. Istilah budaya hukum kuat dipergunakan untuk menggambarkan keadaan masyarakat yang sangat kuat dan kokoh dalam mengikuti dan menaati nilai-nilai hukum yang berlaku di masyarakat. Demikian sebaliknya, budaya hukum lemah merupakan istilah untuk menggambarkan keadaan

"2Taliziduhu Ndraha. Op.Cit. Hlm., 122.

43/bid. 
masyarakat yang tidak menganut dan menaati nilai-nilai hukum yang berlaku di masyarakat atau sangat rendah dalam merespon hukum yang berlaku di masyarakat. .

\section{Deskripsi Hasil Penelitian}

Subjek penelitian ini berjumlah 114 ilmuwan (dosen) yang berpredikat master dan doktor. Lokasi penelitian di UGM, IAIN Sunan Kalijaga, UIl, dan UAJ. Pengambilan subjek penelitian dilakukan secara kuota, yaitu mengambil subjek penelitian dengan jumlah tertentu di masing-masing perguruan tinggi yang dipilih menjadi lokasi penelitian.

Data-data pada penelitian ini dianalisis secara statistik dengan uji beda frekuensi kai kuadrat 1-jalur. Uji beda frekuensi ini bertujuan untuk mengetahui ada tidaknya perbedaan antara frekuensi amatan dengan frekuensi harapan. Frekuensi harapan ini pada umumnya didasarkan atas sebaran yang merata atau terbagi rata. Hasil dari uji beda frekuensi kai kuadrat ini berguna untuk melakukan generalisasi, artinya apakah perbedaan-perbedaan yäng terdapat pada sampel dapat diberlakukan pada populasi atau tidak.

Berdasarkan hasil uji beda frekuensi kai kuadrat 1 -jalur dengan 3 (tiga) kategori budaya hukum ilmuwan tentang hak cipta yaitu kuat, sedang dan lemah diperoleh hasil skor kai kuadrat $(\mathrm{KK})=66.474 \cdot$ dengan derajat bebas $(d b)=2$ dan peluang ralat $(p)=0.00$. Ini artinya ada perbedaan frekuensi budaya-hukum ilmuwan tentang hak cipta yang sangat signifikan antara kelompok.yang kuat, sedang dan lemah. Perbedaan frekuensi yang ada di antara ketiga kelompok pada sampel berlaku juga pada populasi.

Hasil uji beda frekuensi kai kuadrat 1-jalur dengan tiga kategori bu'daya hukum ilmuwan tentang hak cipta yaitu kuat, sedang dan lemah disajikan pada tabel 1 berikut:

Tabel 1.

Kategorisasi Budaya Hukum Ilmuwan tentang Hak Cipta (n=114)

\begin{tabular}{|l|c|c|}
\hline \multicolumn{1}{|c|}{ Kategori } & Frekuensi & Persen \\
\hline Kuat & 19 & 16.60 \\
Sedang & 79 & 69.30 \\
Lemah & 16 & 14.10 \\
\hline Total & 114 & 100.00 \\
\hline
\end{tabular}


- Hasil analisis ketiga kategori budaya hukum ilmuwan tentang hak cipta seperti disajikan pada tabel 1 di atas, lebih lanjut dilakukan uji beda frekuensi kai kuadrat 1-jalur pasangan kelompok yang hasilnya seperti disajikan pada Tabel 2 berikut:

\section{Tabel 2}

\section{Hasil Uji Beda Frekuensi KAI Kuadrat 1-Jalur Pasangan Kelompok}

Budaya Hukum limuwan tentang Hak Cipta

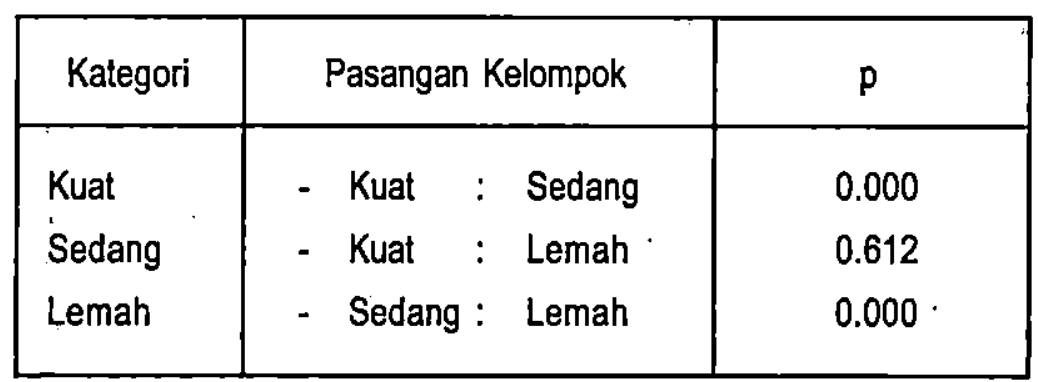

Keterangan tentang kaidah konvensional $\mathrm{p}$ : jika $p \leq 0.010$ artinya sangat signifikan jika $p \leq 0.050$ artinya signifikan jika $p>0.050$ artinya tidak signifikan

Dari Tabel di atas dapat diketahui bahwa hasil uji beda frekuensi 1-jalur pasangan kelompok kuat: lemah skor $p=0.612(p>0.50)$ artinya tidak signifikan, sedangkan untuk pasangan kuat: sedang dan sedang: lemah skor $p=0.000 \quad(p<0.010)$ artinya sangat signifikan. Dari hasil tersebut dapat disimpulkan bahwa budaya hukum ilmuwan tentang hak cipta pada umumnya berada pada kategori 'sedang'. Kategori sedang yang terdapat pada sampel berlaku juga pada populasi.

Dari hasil uji beda frekuensi 1-jalur tentang budaya hukum ilmuwan yang terbagi menjadi kategori kuat, sedang, dan lemah di atas, dapat diwujudkan menjadi diagram Budaya Hukum Ilmuwan tentang Hak Cipta yang disajikan pada gambar berikut: 


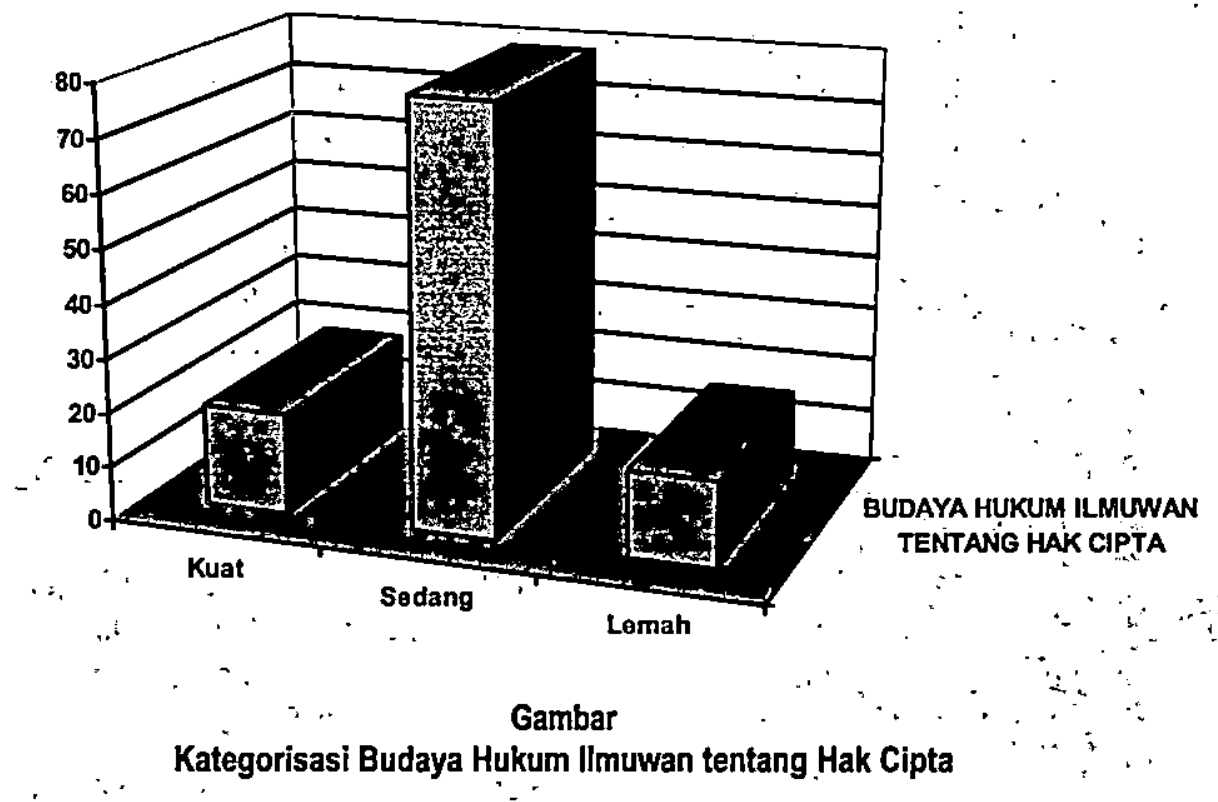

\section{Simpulan}

: Berdasarkan penggolongan budaya ke dalam kategori kuat, sedang dan lemah, budaya hukum ilmuwan tentang hak cipta secara umum termasuk dalam kategori 'sedang': Hasil analisis menunjukkan skor $p=0.000(p<0.010)$ dalam uji beda frekuansi kai kuadrat 1 -jalur yang artinya sangat signifikan, maka dengan hasil ini dapat disimpulkan bahwa perbedaan kuat, sedang, dan lemah budaya hukum ilmuwan tentang hak cipta yang terdapat pada sampel berlaku juga pada populasi. Hasil penelitian ini dapat diartikan bahwa secara umum UndangUndang No.12 tahun 1997 tentang Hak Cipta isinya 'cukup' dipegangi, dianưt; dan tersosialisasikan oleh dan terhădap ilmuwan dalam melakukan' tugas pekerjaàniya, yaitu menulis karya illmiah. Dengan perkataan lain juga dapat diartikan bahwa UUHC cukup signifikan bagi lingkungan dan perilaku. ilmuwan, terutama dalam melakukan kegiatan ilmiah (menulis karya ilmiah). llmuwan menaruh sikap cukup positip terhadap keberlakuan UUHC. Kehàdiran UUHC dinilai; cukup memberikan kepastian, keadilan, dan kemanfaatan bagi ilmuwan dalam menjalankan kegiatan ilmiah. 


\section{Daftar Pustaka}

Adisubroto, Dalil. 1987. "Orientasi Nilai-nilai Orang Jawa serta Ciri-ciri Kepribadiannya." Disertasi. Universitas Gadjah Mada, Yogyakarta.

Almond, Gabriel and Sidney Verba, 1963. The Civic Culture.

Assael, H. 1984. Consumer Behavior and Marketing Action. Second Edition. Boston: Kent Publishing.

Azwar, Saifudin. 1995. Sikap Manusia Teori dan Pengukurannya. Edisi ke 2. Yogyakrta: Pustaka Pelajar.

Darmodiharjo, Darji dan Sidarta. 1996. Penjabaran Nilai-Nilai Pancasila dalam Sistem Hukum Indonesia. Jakarta: PT Raja Grafindo.

Fanani, Ismet. 1992. Plagiat-Plagiat di MIT, Tragedi Akademis di Indonesia. Jakarta: CV Haji Masagung.

Friedman, Lawrence M. 1975. The Legal System: A Social Science Perspektive. New York : Russel Sage Fondation.

1986. American Law. New York: W.W.Norton \& Co.

Hadikusuma, Hilman. 1992. Pengantar IImu Hukum Adat Indonesia. Bandung: CV Mandar Maju.

Hutagalung, Sophar Maru. 1994. Hak Cipta Kedudukan dan Peranannya di dalam Pembangunan. Jakarta: Akademi Pressindo.

Lev, Daniel S. 1990. Hukum dan Politik di Indonesia, Kesinambungan dan
Perubahan. Terjemahan Nirwono dan AE Priyono. Jakarta: LP3ES.

- Luthan, Salman. 1989. "Delik Hak Cipta." Makalah 'Diskusi Jurusan Hukum Pidana FH UII. 24 Agustus 1989.

MD, Moh. Mahfud. 1999, "Pewadahan Etika Keilmuan di dalam UU Hak Cipta." Jurnal Hukum No.12 Vol. 6 1999, 2000. Pergulatan Politik dan Hukum di Indonesia. Yogyakarta: Gama Media.

Ndraha, Taziduhu. 1997. Budaya Organisasi. Jakarta: PT Rineka Cipta.

Radbruch, Gustav. 1950. The Legal Philosophies of Lask, Radbruch, and Dabin. Cambridge. Massachusetts: Harvard University Press.

Rahardjo, Satjipto. "Keluasan Reformasi Hukum." Kompas. 8 Mei 1998.

. 1980. Hukum dan Masyarakat. Bandung: Angkasa.

. 1991. IImu Hukum. Cetakan III. Bandung: PT Citra Aditya Bakti.

Rokeach. 1978. The Natural of Human Values. New York: The Free Press.

Saidin. 1995. Aspek Hukum Hak kekayaan Intelektual (Intellectual Property Right). Jakarta: PT Raja Grafindo Persada.

Sears, et.al. 1988. Psikologi Sosial Jilid I. Terjemah. Jakarta: Erlangga.

Soekanto, Soerjono dan Soleman B. Taneko. 1983. Hukum Adat Indonesia. Jakarta: Penerbit Rajawali. 
M. Syamsudin. Budaya Hukum Ilmuwan tentang Hak Cipta: ...

Soekanto, Soerjono, et al. 1994. Antropologi Hukum, Proses Pengembangan IImu Hukum Adat, Jakarta: CV Rajawali. 1988. Disiplin Hukum dan Disiplin Sosial. Jakarta: Rajawali Press.

Wignjosoebroto, Soetandyo. 1994. "Masalah Metodologik dalam Penelitian Hukum Sehubungan dengan Masalah Keragaman Pendekatan Konseptualnya." Makalah dalam Forum Komunikasi . Hasil Penelitian Bidang Hukum. 5-8 Desember 1994.
Republika, 9 Januari 1999.

Kompas, 28 Desember 1999.

Undang-Undang' Dasar Republik Indonesia.

Ketetapan Majelis Permusyawaratan Rakyat RI Nomor IV/MPR/1999 tentang GarisGaris Besar Halauan Negara.

Undang-Undang Nomor 12 tahun 1997 tentang Hak Cipta (Lembaran Negara Rl tahun 1997 Nomor 29). 